\title{
Statement by H.E. Mr. Tsakhia ELBEGDORJ, President of Mongolia at the 67th Session of the United Nations General Assembly
}

\author{
Mr. President, \\ Mr. Secretary General, \\ Excellencies, and Ladies and Gentlemen.
}

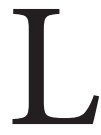

ast year, Mongolia observed the fiftieth anniversary of joining this important body. Thanks to the choice of our free people, this herder's son is here today - happy to report on Mongolia's progress building a strong and free society. Over twenty years ago, Mongolia stood at a crossroads. The flag of democracy was firmly planted in our rich and historic soil.

In the cold winter of 1989 and in the spring of the White Horse Year of 1990, decades of rule without the consent of the governed were swept aside. Individual rights and liberties prevailed. Our revolution did not break a single window. Not one drop of blood was shed.

Mr. President,

More than two decades later, Mongolia is a stable beacon of self-governance, the initiator of the Asia Partnership for Democracy and the leader of the Community of Democracies. We proudly chair this world movement for freedom.

Mongolia has demonstrated a firm commitment to transparency, accountability and the rule of law. We've recognized that this is the only way our democracy can succeed. Therefore, we also cannot tolerate public corruption at any level from the highest officials to the ordinary citizen.

Corruption is like an infectious disease, growing in the dark, eating away at the public trust, scaring away investors, robbing average citizens of opportunities and attacking the vital immune system of a nation. We must shine a light on corruption and attack it head on.

Additionally, our track record of free and fair elections, and peaceful transfer of power from one party to another, can serve as an example to our sister democracies around the world. Mongolia is moving toward more direct and participatory democracy. We are empowering our people, not the government. Mongolia is proud to be the democratic anchor in the East. 
Mr. President,

No democracy is ever perfect. We have experienced similar challenges that other young democracies have. Democracy does not end with casting a ballot. That is just the beginning. Mongolia is uniquely situated in many levels, democratically, economically and geographically. Our drive for transparency and hope for peace makes our nation a vital regional player. Economically, we are blessed by extraordinary growth - nearly seventeen percent last year. Keeping up with our high rate of growth is a very real challenge. It is one that we are prepared to meet head-on.

We are very focused on balancing two goals: First: sharing the opportunities created by our economic success with all Mongolians, and Second: demonstrating clearly and firmly that Mongolia is open for business and a fully engaged member of the international community. Our nation's needs are significant - improved infrastructure, better healthcare, and world-class education. We have much to do to meet the immediate and long-term needs of our people. Our people are the key to our success. We need to invest in their future. We need to invest in both social and economic infrastructure. We are committed to making the investments needed to give our children the bright futures they deserve.

Mr. President,

As an emerging leader of the global community, Mongolia also has important international priorities. None is more important than protecting our environment. All nations must work to preserve our planet as our economies expand and mature. I was honored and humbled to be recognized by the United Nations Environmental Programme, this year for work we are doing in Mongolia to preserve our precious environment. We are committed to doing even more.

Another priority for Mongolia is expanding human rights. Mongolia has established an effective moratorium on capital punishment. We are seeking to permanently abolish the death penalty in Mongolia by legislative action very soon. Government is created by people - so no government has the right to take the life of those who created it.

Let me be clear: Capital punishment is ineffective and barbaric.

Mr. President,

Mongolia cares deeply about safeguarding global peace. We must preserve our planet by eliminating nuclear weapons across the world. We are also firmly opposed to storing nuclear waste on Mongolian soil.

We celebrate twenty years of enjoying a nuclear free weapon status. I am grateful that on September Seventeenth, the five permanent members of the Security Council - the People's Republic of China, France, the Russian Federation, the United Kingdom and the United States, signed a joint declaration reaffirming that status for Mongolia. 
The Mongolia and Nuclear Free Weapon Zone dialogue, initiated and led by Mongolia, continues to make progress. We will host an event in 2015 to make even more. While nuclear power may remain a viable energy option for some, any nuclear energy program in development must submit to the permanent supervision of the United Nations and the International Atomic Energy Agency. Any nation seeking to build nuclear power must not endanger the peace and security of their independent neighbors. The solution to these challenges is engagement, not isolation. The solution is more diplomacy, more dialogue and more action.

Mr. President,

Now more than ever, it is clear that words alone are not enough. We must be unified in taking action to preserve peace. This goal is even more imperative in light of the conflicts that have grown ever more tense in areas like the Middle East.

I was very saddened by the death of the Ambassador and others in Libya. The mission of diplomacy is peaceful. Attacking diplomatic compounds are violation of both the letter and spirit of international law.

Today, I join with Mongolia's allies in condemning the needless violence and bloodshed in Syria as well. Last year, I urged action. This situation started peacefully, but was met with violence from the Syrian government.

Each day...each hour and indeed...each minute - the situation grows worse.

In crises like Syria, we must remember that those dying are not just citizens of that nation. They are also citizens of our planet. Therefore, they are our brothers and sisters, too. The world should be unified and direct in bringing this bloodshed to an end before another life is needlessly lost.

Young girls and boys should be in school, studying for their future, building their dreams. Young girls and boys, as well as their mothers and fathers, should not be dying in the streets and living in nightmares.

This is not a television program. We, members of the United Nations, are not spectators. This body was not created just to watch the show unfold on our TVs. We have to act. We have to move.

Mr. President,

Too many mothers suffer when their children struggle - whether it is for lack of human rights or economic opportunity. Mothers want their children to be free. They want their children to have a job. They want a better life for their children.

My 92 year-old-mother reminds me daily to serve all people with respect - especially women, children and the elderly. Women are the backbone of the family and the bedrock of a nation. They bring life into the world. They sense the cries of an infant. Their instincts are to care for the old, the sick and those in need. Our mothers, sisters and daughters share a core value of caring for others.

We need more women leaders. Women tend to see the whole picture. For society to advance, we need more women in public service at all levels - local to 
global. They bring a unique perspective often missing in global challenges.

Have you ever heard of a woman bloody dictator or tyrant? I think not. If there were more women in power, I think we would have more harmony, more engagement and less suffering and less conflict.

I'm proud to report that in our last elections, we tripled the number of women in parliament.

Mr. President,

The way to empower women is to ensure girls share the same education opportunities as boys. Education is the most basic human right. It is the fundamental building block for human development and free societies.

We owe our children - all of them - the doors that a strong education can open. Instead of weapons, we should invest more in education. It unlocks the potential of every child.

The return on investment will be higher - for both the young men and women of tomorrow and for the world. Educated nations are more secure economically, respect human rights and have greater political freedom.

Mr. President,

In closing, I am happy to report Mongolia's incredible forward movement and renew our commitment of being a part of the community of nations. We accept both the rights and responsibilities that come with that honor.

Eight hundred and fifty years ago, our great King Chinggis Khan was born. $\mathrm{He}$ built the largest land empire in the history of the world. This great King did not erect a single statute to himself.

Chinggis Khan famously noted, "It was easier to conquer the world on horseback than to dismount and try to govern."

Let's be frank. It's not easy to be a diplomat in a troubled world. It's not easy to fight for equal opportunities for all. It's not easy to shine a light on corruption. It's not easy to govern by the rule of law. It's not easy to build real democracy.

It is easier to build statues. It is easier to destroy. It is hard to govern well.

But we all must dismount and govern and govern well. That is vital in order to build a world where our children feel safer...A world where our families are stronger...A world where all nations can prosper.

That is the legacy real leaders need to build - not statues, but opportunities for all mankind.

Mr. President, Mr. Secretary General, distinguished leaders, ladies and gentlemen, I thank you very much. Let's build opportunities for all together. 